\title{
Theatre and Performance Studies in English: An Introduction
}

\author{
Isabel Guerrero \& Verónica RodríGueZ
}

The authors of this Introduction write from two countries and with two backgrounds that are directly relevant to the title of this special issue. They write from Madrid (Spain) and London (UK). The authors originally studied a degree called Filología Inglesa in Spain (we can translate Filología Inglesa as English Studies). Filología Inglesa and its tradition is exactly the raison d'être for the words 'in English' in this RAEI Special Issue's title. This not only means that this Issue features articles about theatre and performance in English but also that it analyses theatre and performance from English-speaking countries.

This may be considered limited indeed in the context of debates around global identity and calls for the decolonization of the curriculum, which is part of a movement that has been called 'Decolonise the University'. It was the removal of the statue of Cecil Rhodes at the University of Cape Town in 2015 that kick-started the Decolonise the University movement across the globe. Another debate is the one about the Global North and the Global South, which has recently morphed into a focus on the term Global Majority (a concept still in the making; sometimes also written as Black and Global Majority people or Black, Global Majority and Indigenous people). In this context, Black, Global Majority and Indigenous scholars as well as artists and people that support this cause demand a commitment to long-term decolonisation processes and the demise of the neoliberal university.

Despite the limitations of this Special Issue in relation to the above, we wanted to acknowledge these crucial contexts in our process of edition and be as diverse and inclusive as possible in our selection of articles and topics. Again, the words 'diverse' and 'inclusive' are problematic too. In the article "A Manifesto to Decentre Theatre and Performance Studies", Swati Arora includes Angela Davis's critique of the concept 'diversity', which she often extends to 'inclusion' to ask questions about the concept that matters to her, justice: 
I have a hard time accepting diversity as a synonym for justice. Diversity is a corporate strategy. It is a strategy designed to ensure that the institution functions in the same way that it functioned before, except now you have some black faces and brown faces. It is a difference that does not make a difference. Diversity without structural transformation simply brings those who were previously excluded into a system as racist, misogynist, as it was before. (Davis 2020 as cited in Arora 2021, 13)

But that's not the only challenge. The title of this Special Issue in itself may be read like an oxymoron. English Studies in Spain has a strong textual tradition, which means that the study of theatre and performance in Spain has been ubiquitously understood from the perspective of literature, that is, in this case, of drama. This leaves us questioning for now the words 'theatre' and 'performance' in the title. Another intriguing aspect to dissect is, why don't we translate Filología into English as Philology? Well, although philology exists as a word in English, generally, Philology doesn't exist as a discipline in the UK and other English-speaking countries.

In Spain, if someone wants to study Theatre and Performances Studies, they may realise very soon that it is not a straightforward route, and the following is one of the main reasons why. The two mainstream ways to access the study of this/these discipline/s in Spain is/are: via courses that focus on language, literature and culture of the theatre tradition studied, or courses that directly train the student as a theatre maker. In other words, either via Departments of 'Philology' that include some modules that focus on the study of drama or via a Theatre School or Conservatory. In the first, the approach to learning theatre and performance (generally drama, due to their textual tradition) is theoretical, most of the time, exclusively. In the latter, the approach to learning is mainly practical with some opportunities for critical and theoretical engagement. There are (Anglophone) universities and institutions that offer Performing Arts as a course in Spain at present, but this is a recent development and not a main route (at least yet) for someone wanting to study theatre and performance in Spain.

This means that studying Filología Inglesa (or its contemporary equivalent, Estudios Ingleses, and other courses and disciplines that focus on textual tradition, like Comparative Literature) will unlikely feed a prospective student's hunger for theatre and performance (in English), and neither will courses in Fine Arts, most of which, will at least, cover to some extent Performance Art. This is so much so that one of the editors of this Special Issue studied simultaneously Filología Inglesa and Arte Dramático (literally, Dramatic Art, but meaning, the course studied in a Spanish public theatre school) and currently is both a theatre 
academic and a theatre director. The journey for the other author was doing an MA in Comparative Literature and ending up teaching drama, theatre and performance in the UK and engaging with several aspects of theatre making, including writing, acting, dramaturgy, directing and production.

You may have spotted already the ongoing 'problem' of the words 'drama', 'theatre' and 'performance', at the very least when we try to think about them alongside the above landscape. Philology-related courses cover drama in most cases, which, as discussed, implies a robust textual tradition. After all, those courses are studied in Departmentos de Filología. However, this approach has opened up in the context of the growing Theatre and Performance Studies discipline/s slowly making their way into the academia. Therefore, although these Departments still focus on text, they have analytically and critically expanded into the field/s of Theatre and Performance Studies, non-exhaustively, as a result of the impact of performance itself and the irruption into the mainstream of work that experiments with and beyond the dramatic text. In this expanded approach, analysis goes beyond the text, but the text may remain the core analytical element.

In the case of the UK, the shift from Drama to Theatre and Theatre and Performance is perceived, for instance, in the extension of Department's names, to include the words Theatre and sometimes both Theatre and Performance, or, internationally, variations that may include words such as 'practice' and 'arts' or even 'science' or 'technologies', to name but a few. Other Departments in the UK keep the term 'drama', such as Queen Mary's, University of London's Department of Drama, which belongs to the School of English and Drama (all of which makes sense in relation to the discussion above). However, you may then look at Staff's titles to discover that some of them may be 'Lecturers in Drama, Theatre and Performance' (a tripartite division ardently criticized, for instance, by Richard Schechner). Keeping the three notions is also true of numerous BA titles across UK Universities, including Roehampton University, University of Sussex and Lancaster University. It has been indeed a long (unfinished) road since the University of Bristol offered a degree in Drama for the first time in the UK in 1947.

Theatre and Performance Studies have made, little by little, their way into academia. The field is relatively new if compared to other disciplines in the Humanities, such as Literary or History Studies. We can say that it is a $20^{\text {th }}$ century phenomenon. Its main precedent is of course the study of Drama. The word drama, "forged from the dialogic tradition" (Wilcox 2020, 268), is invoked when there is a focus on text, which is often referred as a play. Drama, as we have already alluded to, is often (but not always) "taught in literature departments as the study of a particular genre of literary text" (Fisher-Lichte 2014, 12). Literary 
genre: drama. Dramatic text: play. But this began to be perceived as limiting and insufficient in the early twentieth century.

In the English-speaking world, Theatre Studies, "a discipline based on performance rather than literature" (Fisher-Lichte 2014, 13), made its appearance in 1914, with the first Theatre Studies degree programme being taught at the Carnegie Institute of Technology (USA). Although the word 'drama' was still used, the focus was Theatre Studies, as we came to know it later on: "the Carnegie Mellon University's School of Drama, founded in 1914, became the first to offer a degree-granting program in drama with an emphasis on practical training that prepared for a career in the performing arts as well as radio, and later film and television" (Fisher-Lichte 2014, 14).

But the theatre tradition that made history as far as the establishment of Theatre Studies is concerned was the German. In fact, the most important figure in creating and moulding Theatre Studies was Max Herrmann (1865-1942). "[I] nspired by the work of Max Reinhardt (1873-1943), whose productions turned away from the traditional proscenium stage" (Fisher-Lichte 2014, 12), Herrmann argued that the new discipline of Theatre Studies should focus not on literary texts but on performance, arguing that performance was the most important element of theatre. In 1918, Herrmann articulated a difference between drama and theatre that is central to the way Theatre Studies is now conceived not only in German-speaking but also in English-speaking countries and beyond. He wrote that theatre and drama are "fundamentally opposites ... drama is a literary creation of one author, while theatre is the accomplishment of the public and those serving it" (Herrmann 1918)" (Fisher Lichte 2014, 12). Crucially, "Herrmann was interested in the interrelationships between the physical bodies of actors and spectators" (Fisher-Lichte 2014, 14).

This means that the German Professor Max Herrmann is considered by many the 'founder' of Theatre Studies, as he decided to pay attention to the staging, and not only concentrate on the study of the dramatic text. Significantly, this attention to the staging coincides with the emergence of the modern stage director as an individual in charge of orchestrating everything that takes place on the stage as well as the development of the avant-garde movements. At this time, "Theatre Studies turned increasingly toward practical training while the theory of theatre and drama remained within the domain of literature departments (Roach 1999)" (Fisher-Lichte 2014, 14).

Slowly but importantly, academic attention diversifies and focuses not only on theatre itself, but on all sorts of performative events related to human activity, which conferred to the discipline the name of Theatre and Performance Studies. But this must be considered alongside Performance Studies itself developing as a field. While "Theatre Studies was consolidated as a discipline 
during the 1980s as a result of dissatisfaction in academia at the inadequacy of an exclusively literary-based approach to the text, premised upon its ostensible permanence and immutability" (George, Green and Wheeler 2018, 108), "[i]n the 1970s, a third field developed that sought to emphasize the academic research and study of performance outside of the familiar frame of drama and theatre" (Fisher-Lichte 2014, 14).

Propelled by the avantgarde scene in the US in the 1960s, Performance Studies, coined as a term by Richard Schechner, developed as a discipline in the 1960s and 1970s and was also consolidated in the 1980s. Two major events in this direction were the renaming of the Drama Department at NYU into Performance Studies in 1980 and the 1981 "World Conference on Ritual and Performance" organised by the so-called 'fathers' of Performance Studies, Victor Turner and Richard Schechner. Performance Studies generally looks at "non-theatrical cultural practices that share performance characteristics with theatre" (Allain and Harvie 2014, 8). This goes from a funeral to a football game; from Native American rituals to getting ready to go out. Needless to say, Performance Studies looks at performance. In performance, "the performative aspects take precedence over literary and textual elements" (Wilcom 2020, 268).

Theatre and Performance Studies (even more Performance Studies) are still in its infancy in Spain in comparison to the UK, and of course, in much bigger proportions, to the US. Proof of Performance's infancy in Spain is that this volume features more articles on theatre than on performance. This is something that reflects the proposals sent and begs the question about the state of the interest in Performance Studies in English (in/from Spain). At least, what seems clear is that people writing about theatre in English (and who may have been exposed to this call for papers) remain strongly within the dramatic (and theatre) tradition.

From a textual perspective and tradition, scholars are writing increasingly about 'theatre'; they analyse 'theatre' by looking at any performance elements, including but beyond text. But that's obviously not mainly what we mean by 'performance' in this Special Issue's title. Indeed, one of the aims of Performance Studies is to disentangle itself from performance as understood uniquely as a phenomenon that is "constituted in the moment of encounter and interaction between actors and spectators" (Fisher-Lichte 2014, xiii). Nevertheless, as mentioned, we recognize that there is an increasing academic analytical tradition that embraces text as well as other performance elements. In other words, we detect an integrated approach to analysing theatre and performance.

However, it is vital to note that the term Theatre Studies indicates a shift that marked not only the interest in text as only one of many of theatre's elements, but also in practices of signification that go beyond the theatrical event itself, including for instance training. The term Performance Studies suggests a 
decoupling of performance from Performance and embraces all forms of cultural performance. When it comes to analysis, Theatre Studies explores performance (staging and beyond), which includes text as one of its elements, while Performance Studies looks at performance and may include the study of theatre (see Fisher-Lichte 2014, 14), but not drama.

To make things even more complicated, the strong influence of postmodernity and then of influential concepts such as Hans-Thies Lehmann's postdramatic theatre have undone a clear distinction between theatre and performance and the way we analyse theatre and performance. Lehmann's own words on the postdramatic signal unmarking, as he understands postdramatic theatre both as "a rupture with and a continuation of traditional drama" (Boyle, Cornish and Woolf 2019,33). To add to the complexity, the same piece may be called dramatic and postdramatic by different scholars (take for instance the case of Sarah Kane's Blasted).

What we can say though is that, generally, "Theatre and Performance Studies is concerned, most fundamentally, with the study of performances" (Fisher-Lichte 2014, ix). Taking into account that "Theatre and Performance Studies has had a different history in different national contexts" (Fisher-Lichte 2014, 12), what is perhaps most relevant to this Special Issue is that Theatre and Performance Studies has "often been connected to both innovations [...] and broader political developments" (Fisher-Lichte 2014, 12).

Filología Inglesa (at present, mainly called Grado en Estudios Ingleses) should continue pursuing its goals and so should Escuelas de Arte Dramático, no doubt, but this Introduction is undoubtedly a call to the creation of Theatre and Performance Departments across Spain. And not only that, theatre and performance should also be taught at schools and high schools. While this slowly sinks into Spanish Universities' psyche and Spanish governments themselves, we have something else to do, which is introducing the articles in this Special Issue, which we hope will be a small step towards the study of theatre and performance in Spain, in English, yes certainly, but, somehow, beyond Spain and beyond English.

The present Special Issue consists of eight articles divided into four thematic sections entitled respectively: "The Performance of Alternative Victorian Femaleness"; "Performing Politics and Aging"; "Theatres of Violence"; and "Activating Community: From Satire to Location". Each of these sections are briefly introduced, followed by a short summary of the articles. This Special Issue, thus, aims to contribute to this expansive field, encompassing a series of arti- 
cles that examine performative and theatrical events from different perspectives in the field of English Studies.

The $19^{\text {th }}$ century was key for many of the intellectual and artistic ideas that set the foundation of $20^{\text {th }}$-century society. The artistic movement known as Romanticism was especially prolific in the visual arts, literature and music, which influenced each other and set the basis for the avant-garde in the $20^{\text {th }}$ century. Although, in the theatre, this period is usually remembered for the many unsuccessful attempts to meet the criteria established by Victor Hugo in his "Preface to Cromwell", theatre was not only a site for romantic experimentation, but also for the introduction of ideas about social change. The articles in the section opening this special issue, "The Performance of Alternative Victorian Femaleness", show how theatre and performance were active agents in the construction of an alternative female identity beyond the Victorian idea of women as the angel in the house.

In "Performing the Female Alternative in Victorian Popular Drama: The "Girl of the Period' and the 'Fast Girl'", María Victoria Puchal explores the popularization of theatergoing in $19^{\text {th }}$-century London and the social issues addressed by the drama of the times. She focuses on two mid-century plays, Our Female American Cousin (1860), by Charles Gayler, and My New Place (1863), by Arthur Wood, to examine how they introduce the fight for women rights thanks to their depiction of female characters. Although these characters are not perceived as positive, as Puchal argues, their appearance in the plays is an indication of the relevance of transgressive female identities.

Mayron Cantillo focuses on performativity beyond drama in her analysis of Michael Field's poem Long Ago in the article “'Come, Dark-eyed Sleep': Michael Field and the Performance of the Lyric as a Radical Fantasy". Michael Field was the pseudonym of two $19^{\text {th }}$-century female authors: Katharine Bradley and Edith Cooper. The article approaches Fields' poem with Jonathan Culler's theory of the lyric as a performative genre to analyse the performative dimension of the text. The poem, thus, is used as a case study to explore Field's poetic theatricality thanks to pictorial and performative power.

The second section in this volume, "Performing Politics and Aging", groups two articles that, albeit focusing on the analysis of drama, bring to the foreground the performing dimensions of, first, politics, and, second, aging. As social constructs, both politics and aging are constantly negotiated. Not only politics is often discussed in theatre and performance but, throughout history, politics has also used theatre to serve its own purposes. Aging might be, at first sight, a biological construct, but many of the ideas we associate with it are also conditioned and are part of a social performance that theatre has often re-enacted.

In "Performing Political Persuasion in the United States in the Early Years of the Republic", Tomáš Kačer examines the role of theatre to create a national 
identity in the aftermath of the Revolutionary War in the US. To do so, he examines the theatre productions of Joseph Addison's Cato at Valley Forge in 1778, William Dunlap's André at the New Park in New York in 1798 and Bunker-Hill by J. D. Burk at the Haymarket in Boston in 1797. Through the analysis of several performative aspects of these productions, the article examines the role of theatre in the formation of the US as a new, independent nation.

Regarding aging, Núria Casado-Gual and Inesa Shevchenko-Hotsuliak shed light on how the complexity of old age and its gender implications has been traditionally disregarded in drama and its theoretical analysis in "Disrupting Temporalities, Multiplying the Self: An Age-Studies Approach to Two Contemporary Plays". As a response to this invisibility, they select two plays that show the multi-layered identity of aging and present female characters on the stage: Michel Tremblay's Albertine in Five Times (1984) and Matt Hartley's Here I Belong (2016). In spite of the thirty-year gap between the two plays, the authors of the article find many similarities in their treatment of old age and claim that these playscripts pave the way for an anti-ageist society.

To turn to this volume's third section, "Theatres of Violence", a contemporary inevitable reference, given the allusion to Black Lives Matter in its first article, is the murder of George Floyd. For how long can someone keep their knee on someone's neck? Derek Chauvin kept his knee on George Floyd's neck for 8 minutes and 46 seconds on 25 May 2020. The stark inhumanity humans are capable of keeps happening over and over again, and overwhelmingly targeted at specific groups. The outpour that followed George Floyd's murder was a marked moment in the long, ongoing struggle against police (and system and systemic) brutality towards the Black community.

How long will it take for our generation to forget Floyd's "I can't breathe"? Hopefully, we will never do. Memory is such a key strategy to resort to in relation to violence because unfortunately, violence against Black people is a persistent and ongoing event. Lucy Nevitt, for instance, writes in Theatre \& Violence of violence as "prolonged, ongoing or repeated" $(2013,5)$.

In "Performative Encounters: Memory Violence in Sleep Deprivation Chamber", Paula Barba Guerrero discusses the biographical play Sleep Deprivation Chamber (1996) by Adrienne Kennedy and her son Adam P. Kennedy. Barba argues that the play manages to insert unrecorded moments of abuse in our collective imaginary, moving from staged nightmares, distant courtrooms and individual sleep deprivation chambers into a figurative shared space where black lives do matter.

In the second article, entitled "Adaptation against Myth: Gary Owen's Iphigenia in Splott and the Violence of Austerity", Rebeca Gualberto Valverde explores Gary Owen's Iphigenia in Splott (2015), a contemporary British adaptation of 
Euripides's Iphigenia in Aulis. Owen situates the story in the context of austerity policies in the UK. Firmly placing the adaptation in the context of political theatre, Gualberto discusses myth as the 'ethical' framework that legitimises Effie's suffering. Equating myth discourse and the austerity narrative, she argues that Iphigenia in Splott is an adaptation that works against myth.

The fact that Barba Guerrero's and Gualberto Valverde's articles are presented together in the same section is a stark reminder that there will be no justice for marginalised groups in societies until there is no equal access to dignity, opportunities and resources. As Edward Bond himself puts it, "[W]henever there is serious and constant violence, that is a sign of the presence of some major social injustice" $(1977,13)$, which points out to the idea that "violence has a relationship to power and powerlessness" (Nevitt 2013, 6).

To proceed with the fourth and final section, "Activating Community: From Satire to Location", we sometimes invent new forms; some other times, we revise existing forms for the times we live in, to speak about the present. Satire comes and goes. There is perhaps no other form right now that can mean so much to the times we are living. When existence becomes ridiculous and the everyday absurd, what is the most fitting form? We live in a period of informants, surveillance and control once again. When power closes us in so forcefully and darkly, one of the only avenues left is laughter, humour and satire.

Oluwafemi Alabi's "An Exploration into the Satiric Significance of Abuse in Selected Nigerian Drama" taps into the political potential of satire by looking at the socio-political relevance of linguistic abuse in contemporary Nigerian Drama, focusing on the playwrights Femi Osofisan and Ola Rotimi. Going beyond a comedic purpose, Alabi argues that invectives in Osofisan's Altine's Wrath (2002) and Ola Rotimi's Who is a Patriot? (2006) crucially address some socio-political realities such as oppression, exploitation, resistance, self-interest versus national interest, and capitalism.

Something similar goes for community. What is the significance of community when communal events are wiped off our diaries and we can no longer be one body in a single space? What is community when the only assemblage of bodies willingly allowed by the state is today's circensis, aka football? Fear is the ingredient that instils distance (not uniquely physical) between bodies and the pandemic has only exponentially increased fear. We are at a cliff edge, but nobody wants to look. Will a reinvention of community that cares about bodies and our main body, the planet, lead the way towards a possible future?

Kerrie Reading's article, "Navigating New Approaches for Grassroot Community Theatre in a (Post)-Covid World", explores how theatre makers in Britain might navigate former approaches to alternative and community theatre making, including discussion of work by companies such as Common Wealth Theatre 
and Theatre and Women, as a way to create live work in a (post)-Covid world. Kerrie posits that locality (and the forged connections between people and place) will be a key component to how theatre is made as we emerge from the worldwide crisis generated by Covid-19.

Whether there is a future or not, we must decentre and embrace multiplicity now. So, back to the idea of decentring and the opportunity brough by the fact that theatre and performance in English (in/from Spain) as well as Theatre and Performance Studies in Spain are young phenomena, what seems clear is that "the discipline needs to interrogate what it deems 'theory' and embrace a multiplicity of knowledge systems as vital to our pedagogy" (Arora 2021, 17).

And yes, that's right, no matter how many times Schechner repeated this: "Performance is about more than the enactment of Eurocentric drama" (Schechner 1992, 9), Theatre and Performance Studies is a Eurocentric discipline, often Anglo-centric, and exercises in decentring, no matter how precarious they are, are still small steps in the best direction we can take.

We are certain that we have not solved any disciplinary debates, answered any questions or offered a comprehensive picture of the field in this Special Issue. And yet, we hope that this Volume and its gestural politics are just an introduction towards what may be ahead and what we may become as a country that cares for the teaching and learning (and making) of theatre and performance.

\section{Works Cited}

Allain, Paul and Jen Harvie. 2014. The Routledge Companion to Theatre and Performance. New York: Routledge. https://doi.org/10.4324/9781315779010

Arora, Swati. 2021. "A Manifesto to Decentre Theatre and Performance Studies." Studies in Theatre and Performance 41 (1): 12-20. https://doi.org/10.1080/14682761.2021.1881730

Bond, Edward. 1977. Plays One. London: Methuen.

Boyle, Michael S., Matt Cornish and Brandon Woolf, eds. 2019. Postdramatic Theatre and Form. London: Bloomsbury Methuen Drama.

GeorGe, David, Stuart Green and Duncan Wheeler. 2018. "Spanish Theatre Studies: Beyond the Text." Hispanic Research Journal 19 (2): 108-116. https://doi.org/10.1080/14682737.2018.1444430

FisCHER-Lichte, Erika. 2014. The Routledge Introduction to Theatre and Performance Studies. Edited by Minou Arjomand and Ramona Mosse. Translated by Minou Arjomand. London and New York: Routledge. https://doi.org/10.4324/9780203068731

Nevirt, Lucy. 2013. Theatre \& Violence. Basingstoke and New York: Palgrave Macmillan. https://doi.org/10.1007/978-1-137-30228-1 
SCHECHNER, Richard. 1992. "A New Paradigm for Theatre in the Academy." The Drama

Review 36 (4): 7-10. https://doi.org/10.2307/1146210

Wilcox, Dean. 2020. "Postdramatic Theatre and Form ed. by Michael Shane Boyle, Matt Cornish, and Brandon Woolf (review)." Theatre Journal 72 (2): 267-269.

https://doi.org/10.1353/tj.2020.0056

\footnotetext{
Authors:

Isabel Guerrero

Universidad Nacional de Educación a Distancia (UNED), Spain

iguerrero@flog.uned.es

https://orcid.org/0000-0003-2924-2970

Verónica Rodríguez

University of Reading, UK

veronica.rodriguez.ac@gmail.com

https://orcid.org/0000-0003-0171-7460

Citation:

Guerrero, Isabel and Verónica Rodríguez. 2021. "Theatre and Performances Studies in English: An Introduction.” Alicante Journal of English Studies 35: 7-17.

https://doi.org/10.14198/raei.2021.35.09

(C) 2021 Isabel Guerrero \& Verónica Rodríguez

Licence: This work is licensed under a Creative Commons Attribution 4.0 International License (CC BY 4.0).

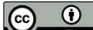

Alicante Journal of English Studies, Issue 35, 2021, pages 7-17 